УДК81'373.612.2:070

DOI:10.31470/2518-7600-2018-6-58-73

\title{
METAPHOR IN MASS MEDIA DISCOURSE
}

\section{МЕТАФОРА В МАСМЕДІЙНОМУ ДИСКУРСІ}

\author{
Овсієнко Алла, \\ аспірантка \\ кафедри документознавства \\ ovsiienko_alla@ukr.net \\ https://orcid.org/0000-0002- \\ 0905-9725
}

ДВНЗ «Переяслав-

Хмельницький державний педагогічний університет імені Григорія Сковороди», вул. Сухомлинського, 30, м. Переяслав-Хмельницький, Київська обл., Україна, 08401
Ovsiienko Alla, postgraduate student of Department of scientific discipline of documentation ovsiienko_alla@ukr.net https://orcid.org/0000-00020905-9725

Pereiaslav-Khmelnytskyi Hryhorii Skovoroda State Pedagogical University, 30, Sukhomlynsky Str., PereiaslavKhmelnytskyi, Kyiv region, Ukraine, 08401

\section{ABSTRACT}

The article deals with the metaphor, which plays as a main component of printed and electronic communications.

The research proves that in the informational sphere the great role is devoted to mass media, which influence historically on modern person's outlook formation. The mass media language as a variety of national language intergrades together with the ethnical consciousness and stays under the influence of social processes. It shows not only a social life, but the country face in general. That is why the language of modern mass media is reach on metaphor, which is formed on architypes and has different stylistic meaning.

The attention in the language of mass media is paid on conceptual metaphor, which is used for reaching of different effects. Its use may be caused by the desire to make a printed word more emotional, influential.

There were made conclusions, that metaphor as a manifestation of creativity of thinking is present in almost every type 
of discourses, regardless of their typology (political, medical, institutional, pedagogical, postmodernist, feminist etc.). However in each discourse the complex of metaphor's functions is specific, depending on different features of actual discourse.

During the communication, in particular in publicist style, metaphor helps to outline main ideas of communicative message, to put axiological emphasis, also appeals to background knowledge of the recipient and activates to association.

For the research of metaphor in publicist style as main the method of observation and descriptive method were used. At different stages of the research the method of functional analyses was used to define the stylistic load of metaphor in journalism.

Keywords: metaphor, conceptual metaphor, mass media, journalism, society.

Постановка проблеми. Феномен метафори, іï сутність типи й функції в різних сферах мовленнєвої діяльності стали об'єктом наукових пошуків ще в часи античності (зокрема у працях Аристотеля, Квинтиліана, Платона, Цицерона) й досі залишаються в колі зацікавлень сучасних лінгвістів. 3 початком лібералізації газетного мовлення в другій половинні $\mathrm{XX}$ століття метафора стала важливим джерелом експресії та комунікативним механізмом у газетно-публіцистичному дискурсі, іiї прагматичний потенціал у сучасних друкованих ЗМІ стало важливим завданням сучасної лінгвістики.

Останнім часом спостерігаємо чимало наукових праць (дисертації, монографії, статті), об’єктом дослідження яких є метафора. Таке розмаїття наукових пошуків пояснюється не тільки традиційним серед філологів трактуванням метафори як тропу, засобу увиразнення мови, а й наявністю нових підходів у тлумаченні цього художнього засобу. Особливого вивчення метафора набуває в публіцистичному стилі, сферою використання якого $\epsilon$ громадсько-політична діяльність, суспільно-виробнича, культурно-освітня та навчальна.

Аналіз останніх досліджень і публікацій. Метафора була об'єктом дослідження багатьох мовознавців Арутюнова Н. Д. (Арутюнова, 1990), Балашова Л. В. (Балашова, 2014), Баранов А. Н. (Баранов, 2004), Гапонова Л. Є. 
(Гапонова, 2013), Лут К. А. (Лут, 2011), Романюха М. В. (Романюха, 2013) та ін.). Метафора в різних проявах відіграє важливу текстотвірну роль у мовних функціональних стилях, особливо в публіцистичному, оскільки допомагає реалізувати інформативну і прагматичну функції.

Питанню метафори в публіцистичному стилі присвятили свої праці такі дослідники як: Келічава Я. Б. (Келічава, 2016), Космеда Т. А. (Космеда, 2015), Мельник П. П. (Мельник, 2014), Одинецька Л. В. (Одинецька, 2017) та ін. Варто зазначити, що в умовах швидкого розвитку інформаційного суспільства комунікативні стратегії засобів масової інформації постійно змінюються відповідно загортання цієї динаміки, особливості функціонування метафори та їі модифікацій у газетному тексті потребують синхронного всебічного вивчення.

Мета статті. Розглянути різні види метафори та їхні функції в засобах масової інформації.

Виклад основного матеріалу. У сучасному інформаційному просторі велику роль відіграють засоби масової інформації, які історично впливають на формування світогляду сучасної людини. Мова засобів масової інформації як різновид національної мови еволюціонує одночасно 3 етнічною свідомістю та перебуває під впливом суспільнополітичних процесів. Тому мова сучасних засобів масової інформації багата на метафори, які сформовані на архетипах та мають різноманітне стилістичне значення.

Проблема функціонування метафори в мас-медіа є однією 3 ключових у сучасній лінгвістиці. Метафора - це один із найпродуктивніших інструментів збагачення мови, водночас це засіб концептуалізації дійсності і формування суспільних поглядів (Панько, 1994: 216).

Першочергова потреба в підборі загальнозрозумілих форм вираження, які б одночасно відрізнялися свіжістю й новизною, спостерігається в публіцистичних текстах. Саме в них бачимо високий ступінь насиченості ідеями, що підтверджує аксіому про те, що «мова публіцистики - це мова i думок, i почуттів». Метафора $\epsilon$ результатом цього універсального двостороннього ресурсу в поєднанні раціонального та творчого мислення, який не тільки поповнює 
лексичний склад мови, а й дає поштовхи для побудови нових парадигм, що формують можливість пізнання та оцінки повідомленого (Панько, 1994: 216).

За аристотелівською концепцією, метафора - це лише «прикраса тексту, звичайне перенесення значення з одного предмета на інший» (Аристотель, 1967: 8), або ж у риторичних ученнях, це «дещо на кшталт удалого виверту, що грунтується на гнучкості слів, як дещо доречне лише в певних випадках, що потребує особливого мистецтва й обережності (Ричардс, 1990: 45). Але на сьогодні, завдяки розробці багатьох підходів до іï тлумачення та тематичного спектру дослідження, метафора розширила свої концептуальні межі. Сформувався новий погляд на поняття в ширшому евристичному контексті, ніж власне мовознавчий. Метафора «пронизує все наше повсякденне життя й проявляється не лише в мові, а й у мисленні й діях, наша звичайна поняттєва система $є$ метафоричною за своєю природою. Метафори як мовне вираження стають можливими саме тому, що вони існують у поняттєвій системі людини» (Лакофф Дж., 1990: 390).

Метафора як прояв креативності мислення присутня практично в усіх типах дискурсів незалежно від їхньої типологізації (політичному, медичному, інституційному, педагогічному, постмодерністському, феміністському та ін.). Однак у кожному 3 дискурсів сукупність функцій метафори $є$ особливою в залежності від різноманітних ознак актуального дискурсу (Романюха, 2013: 220).

Різні метафори мають різне функціональне навантаження в засобах масової інформації. Використання журналістами різних концептуальних метафор допомагає впливати на сприйняття людиною певних явищ i подій, формувати ii світогляд, структурувати людське мислення, навчати прогнозувати альтернативні вирішення тієї чи тієї суспільнополітичної проблеми (Баранов, 2004: 39-40).

Суспільно-політичні події країни часто змінюються, тому для їх характеристики використовують метафори. Кожен суспільно-політичний процес в країні супроводжується творенням та функціонуванням низки нових метафор. 
Журналісти чи публіцисти в своїх виступах, статтях зображують політиків і політику в різних образах (Одинецька, 2017: 14).

Найпродуктивнішим різновидом концептуальних метафор у мові засобів масової інформації є соціоморфна, у якій світ репрезентується як модель соціальних відношень у суспільстві, як людську соціальну діяльність (Балашова, 2014: 632).

Найбільш активно метафоризуються загальновідомі прізвища політичних i суспільних діячів. У сучасному газетному мовленні у зв' язку з загальновідомими політичними подіями простежуємо тенденцію до маніпуляції іменем i прізвищем чинного президента Російської Федерації Володимира Путіна. Спостерігаємо експліцитну й імпліцитну вказівку на цей антропонім 3 моделюванням іронії чи негативної оцінки, що стосується як антропоніма, так і лексем, похідних від нього (Балашова, 2014: 632).

Для моделювання метафори-перифрази на основі актуалізації відповідних власних назв активно використовують контамінацію прізвищ політичних діячів сучасності й минулого на основі врахування чинника «аналогія їх поведінки» (актуалізуються прецедентні імена й прецедентна ситуація), що ілюструвалося на прикладі оказіоналізму Путлер. На основі актуалізації цієї ж моделі утворено антитезу, метафору-онім, що репрезентує мовну гру: це метафоричне словосполучення торкається екс-президента України В. Ф. Януковича: в одному прізвищі поєднуються два - Янукович і Чаушеску (Космеда, 2015: 116), напр.: Янушеск.

На різних етапах існування економічного тексту ці два типи метафор відіграють різні ролі. Так, якщо у процесі інтерпретації адресант спочатку звертається до візуальної метафори, то у процесі породження тексту вербальна метафора $\epsilon$ первинною. Візуальні метафори взагалі можливі лише тому, що спираються на вже існуючу вербальну (Лут, 2011: 83).

Наукова література 3 управлінського консультування породжувала надію, що в «правильному» формуванні організаційної культури ховається ключ до економічного успіху. При цьому, однак, упускати з виду неодноразово 
підкреслюваний Е. Шайном факт, що організаційна культура, як правило, не усвідомлюється iї носіями. Культурна метафора висуває на передній план спільні інтерпретації, колективні цінності і норми, а також міфи та ритуали. Згідно із символічним інтеракціонізмом, якщо людина визначає для себе ситуацію як реальну, то i ïi наслідки будуть для нього реальними. Отже, на противагу бюрократичної моделі люди в організації відіграють більш активну роль: завдяки взаємодії та інтерпретації вони конструюють соціальну реальність своєї організації у складному сплетінні символічних і матеріальних дій і вчинків. 3 кінця 80-х років минулого століття метафора культури стимулює величезну кількість організаційних досліджень, в яких використання якісних методів дозволяло зробити видимою «внутрішне життя організації». У цих дослідженнях було виявлено, що всупереч очікуванням, не існує єдиної культури однієї, окремо взятої організації. Швидше за все мова йде про співіснування інтегрованих (тобто східних), диференційованих (тобто протилежних) i фрагментованих (тобто розрізняються) способів сприйняття i розуміння в організації, які детермінуються громадськими, професійними, функціональними і насамперед ієрархічними відмінностями (Иванова, 2014: 509).

Метафоричні вирази мови не тільки відображають i експлікують метафоричне сприйняття дійсності, а й значною мірою формують його, оскільки означає або допоміжним суб'єктом метафори стають явища, вже концептуалізовані й відображені в значеннях слів.

Тому вивчення системності метафоричних переносів в рамках різних сфер досвіду дозволяє проникнути в структури людського мислення і зрозуміти, яким чином ми уявляємо собі навколишній світ і своє місце в ньому.

Метафору можна розглядати як інструмент дослідження картини світу (Блэк, 1990: 153-172). Вдумайтеся, ми як би відстороняємося від своїх власних органів, наділяємо їх самостійною волею і характером. Одна справа сказати - у мене заболіло серце або печінка. Інше - серце пустує, печінка пустує, та ще додати - зараза така, докорив хворий орган за погану поведінку. Виходить, це не я недосконалий, а так, хтось трохи 
з боку. У таких випадках спрацьовує захисна реакція психіки (Дьяченко, 2003: 426).

Характеризуючи сьогодення, насамперед, в аспекті візуально-смислових конструктів культури, неможливо оминути питання того, що домінуючий вплив на світоглядні орієнтири людини має медіареальність. Отже, необхідним стає виявлення принципів метафоричності самої медіакомунікації, яка у значних тенденціях базується на зоровій репрезентації та сприйнятті інформації. Основа подібності зображеного на електронних носіях інформації видимим об'єктам дійсної реальності $€$ настільки традиційним елементом візуальної ідентифікації, що ми про це і не замислюємось. Образотворчі мистецтва у різній мірі (міметичній, символічній) виходили із цього принципу. I якщо базові смисли попередніх періодів культури були вкодовані у візуальні символи та метафоричні образи скульптури, архітектури тощо, то їх історично-набута поліфонічність у кінці XIX - початку XXI століть потребує профільних знань ідентифікації. Однак на допомогу візуальному мисленню у повсякденності приходить фотографія та інші винаходи, в яких зорова метафора ініціює утворення нових значень. Проте важливим є зауваження, що поступово зображувальний контекст технологічно-сучасної візуальної комунікації дедалі частіше сприймається реципієнтом 3 точки зору хронікальності, фактажності i, зрештою, фактичності бачення світу. У цій оптиці формується діалектичне поставання - від бачення світу до світобачення. Медіареальність формує сьогодні значну долю візуального досвіду людини, проте нівелюється усвідомлення того, що зображена реальність є по-перше, фрагментом, монтажем та, по-друге, у цілісності сприйняття суб'єктом видимого медіаряду становить метафору дійсної реальності як оптичноперенесений смисл зображеного і наявну за визначенням, однак винесену за дужки медіаконтексту, необхідність певної інтелектуально-чуттєвої, інтїтивної процедури доконструювання вказаної цілісності. Йдеться насамперед про сучасний етап розвитку аудіовізуальної комунікації, яка забезпечує створення «самодостатнього» образу світу в інформаційно-медійному бутті особистості. Сам феномен 
віртуалізації реальності є предметом рефлексії різних наук й, відповідно, комплекс проблем, що досліджується, відкриває багато спектрів цього явища. Однак і нині одним із складнопрогнозованих аспектів залишається питання переформатування чуттєвого сприйняття людиною світу в русло метафорично-всепоглинаючої медійної його презентації та рецепції. Складно сьогодні назвати той прояв нашого буття, який би не знайшов відображення в інтернет-мережі або інших інформаційних сегментах медіакомунікації. Не перебільшеною буде констатація такої тенденції, що дійсна реальність сприймається як привід, аргумент іiі віртуалізованої інтерпретації. Осмислення цієї проблеми в контексті історичної логіки розвитку суспільства вказує на очевидний вибір людини на користь зручного, комфортного й малобюджетного ознайомлення із світом, отже, крізь призму екрана монітору. Тобто формування індивідуального візуального досвіду через побачене, відображене, й трансльоване медіа посередником (Покулита, 2015: 74).

Адресат, його статус та конкретні риси в ситуації текстотворення значною мірою впливають на текст. За твердженням О. А. Сербенської, «соціальна природа газетного мовлення, підхід до нього як функціонального різновиду національної мови, що перебуває в складних відносинах зі суспільством і особистістю, вимагає постійної уваги до проблеми людської психіки». Окрім номінативної функції, метаформа має помітну експресивно-оцінну грань, є сильним засобом впливу на емоційно-психологічний стан читача. Теоретичні дані психології і психолінгвістики та численні спостереження за виявленням смислів тексту реципієнтами дозволяють припустити, що емоція, фіксована в тексті, відіграє не лише регулюючу, але i сугестивну роль у розумінні авторських смислів. Для аргументації висунутого припущення наведемо приклад формування яскравих актуальних емоцій, але і сугестивну роль у розумінні авторських смислів. Для аргументації висунутого припущення наведемо приклад формування яскравих актуальних емоцій, що виникають навіть на тлі різних суб'єктивних мотивацій. Асоціативно-смислове поле номінативної емоції «печаль» відображене в 
метафоричному заголовку статті про смерть Валерія Васильовича Лобановського «За ним дощем заплакала Вкраїна». «Національне горе», «величезна втрата», «сум всієї країни» - ось які емоційні асоціації виникають у будь-якого адресата. Скорбота країни передається такими фразами, що розгортають окреслену заголовком тему: «важка втрата», «мороз по шкірі», «чорний день українського футболу». Таким чином, експлікація авторських емоцій шляхом метафоризації важлива не скільки сама по собі, скільки тому, що емоції здачі закріплювати домінантні особливості смислу тексту (Мельник, 2014).

Образність термінів виникає внаслідок метафоричності значень і так само не сприймається в ролі об'єктивного критерію через досить тривале використання загальновживаного слова в контексті української криміналістичної термінології. Наприклад: лама (іспанський автоматичний пістолет калібру 9 мм і 7, 65 мм), боксер (бразильський шестизарядний револьвер 38 спеціального калібру), лось (радянський п’ятизарядний магазинний мисливський карабін калібру 9 мм). Закріплення професійної лексеми чи словосполучення в активі фахівців конкретної галузі знань уже $є$ повноправним критерієм термінної стійкості словосполучень на зразок «свіжий» слід, «жирний» слід, «сліпий» слід, сліди взуття з малюнком «у ялинку», розшук по «гарячих» слідах (Біленчук, 1998: 416) у мікротерміносистемі «сліди локомоційних навичок людини». Подібні терміни, оминувши етап перенесення зі сфери функціонування на сферу фіксації й закріплення, принаймні в спеціальній науковій та методичній літературі 3 криміналістики, засвідчили свій термінологічний статус, мотивованість i водночас продуктивність термінотворення способом вторинної номінації (Гапонова, 2013: 97).

Метафоризація як джерело збагачення літературної мови має важливе значення i в утворенні одиниць, що мають специфічну сферу вживання, зокрема в терміносистемах, однією з яких є термінологія криміналістики. Дослідження формування терміносистеми криміналістики дає підстави 
стверджувати, що на початковій стадії становлення криміналістичної термінології вторинна номінація є одним із продуктивних способів термінотворення. Дослідження таких термінологічних лексем має велике практичне значення 3 огляду на те, що «важливо постійно переглядати терміносистеми $з$ погляду їх адекватності суті номінативних понять, з'ясовувати активні моделі термінотворення» (Панько, 1994: 216), тому подальше дослідження термінології сприятиме розкриттю логіки побудови термінополів у межах терміносистеми криміналістики, а також системи української сучасної термінології загалом (Панько, 1994: 216).

Висновки та перспективи подальших досліджень. Отже, метафора виступає одним із найважливіших компонентів друкованих та електронних комунікацій. У мові засобів масової інформації концептуальну метафору використовують для досягнення різних ефектів. Її вживання може бути зумовлене бажанням зробити друковане слово емоційнішим, впливовішим. За допомогою метафори журналіст може змусити читача замислитися над актуальними питаннями сьогодення, сприяти ствердженню певних світоглядних орієнтирів громадян.

Метафора $\epsilon$ одним 3 яскравих засобів творення публіцистичного образу держави, зафіксованого в публіцистичних текстах. Використання метафор зазвичай продиктоване бажанням досягти ефективності друкованого слова, його дієвості, оскільки публіцистика формує суспільну думку. У будь-якому випадку активне використання метафор у мові засобів масової інформації супроводжується процесами подолання одних стереотипів сприймання тих чи тих реалій i заміщення їх новими, моделювання певної мовної картини світу - своєрідної надбудови над реальністю. Таким чином, метафора $є$ найпродуктивнішим засобом збагачення мови та інструментом впливу на людське мислення.

\section{ДЖЕРЕЛА ТА ЛІТЕРАТУРА}

1. Аристотель. Поетика. Київ: Мистецтво, 1967. 134 с.

2. Арутюнова Н. Д., Журинская М. А. Теория метафоры. Москва: Прогресс. 1990. С. 385-386. 
3. Балашова Л. В. Русская метафоричиская система в развитии: $X I-X X I$ вв. Знак, 2014. 632 с

4. Баранов А. Н. Политический дискурс: методы анализа тематической структуры и метафорики. М., 2004. 84 с

5. Блэк М. Метафора. М.: Прогресс, 1990. С. 153-172.

6. Гапонова Л. Є. Роль метафори у формуванні української криміналістичної термінології. Структура і семантика мовних одинииь. 2013. URL: https://journal.kdpu.edu.ua/ filstd/article/ download/ 515/512/.

7. Дьяченко А. П. Метафоры и терминологически устойчивые выражения в медицине. Минск: Новое знание, 2003. $426 \mathrm{c}$.

8. Келічава Я. Б. Функиіонування метафори у текстах газети "День»: пошук продуктивних концептів. 2016. URL: http:// er.nau.edu.ua/bitstream/NAU/ 24843/1/ stattya_Kelichava. docx

9. Космеда Т. А Метафора сучасної публіцистики: актуалізація антропонімів (на матеріалі української та російської мов). Науковий вісник ДДПУ імені I. Франка. Серія «Філологічні науки». Мовознавство. № 3, 2015. URL: http:// www.irbis-nbuv.gov.ua/ cgi-bin/irbis_nbuv/ cgiirbis_64.exe? $\mathrm{I} 21 \mathrm{DBN}=\mathrm{LINK} \& \mathrm{P} 21 \mathrm{DBN}=\mathrm{UJRN} \& \mathrm{Z} 21 \mathrm{ID}=\& \overline{\mathrm{S}} 21 \mathrm{REF}=$ $10 \& S 21 \mathrm{CNR}=20 \& \mathrm{~S} 21 \mathrm{STN}=1 \& \mathrm{~S} 21 \mathrm{FMT}=\mathrm{ASP}$ meta $\& \mathrm{C} 21 \mathrm{COM}=$ S\&2_S21P03 $=$ FILA $=\& 2 \_S 21 S T R=$ nvddpufm_2015_3_21

10. Криміналістика: ${ }^{-}$[підручник]. П. Д. Біленчук, О. П. Дубовий, М. В. Салтевський, П. Ю. Тимошенко; за ред. акад. П. Д. Біленчука. К.: Атіка, 1998. 416 с.

11. Лакофф Дж., Джонсон М. Метафоры, которыми мы живем. Теория метафоры: Сб. науч. работ. М.: Прогресс, 1990. C. 387-416.

12. Лут К. А. Інтеракція візуальних та вербальних метафор у популярному економічному дискурсі. Нова філологія №44. 2011. URL: http:// www.irbis-nbuv.gov.ua/ cgibin/irbis nbuv/cgiirbis 64.exe?I21DBN=LINK \&P21DBN=

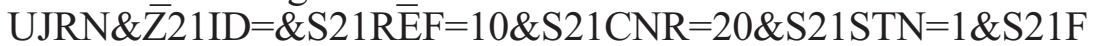
$\mathrm{MT}=\mathrm{ASP}$ meta\&C21COM=S\&2 S21P03=FILA=\&2 S21STR $=\mathrm{n}$ vddpufm_2015_3_21

13. Мельник П. П. Нове метафоричне мислення в газетній спортивній журналістиці. 2014. URL: http:// journlib.univ. kiev.ua/ index. php?act $=$ article \&article $=1062$. 
14. Одинецька Л. В. Роль метафори в засобах масової інформаиіï. 2017. URL: http://enpuir.npu.edu.ua/handle/ $123456789 / 13506$

15. Панько Т. I. Українське термінознавство: [підручник]. T. I. Панько, I. М. Кочан, Г. П. Мацюк. Львів: Світ. 1994. 216 с. URL: http://g.lekciya.com.ua/doc/2312/index.html.

16. Покулита I. К. Зорові метафори культури у візуальносмисловому сегменті медіа комунікаціi. 2015. URL: http://novyn.kpi.ua/2015-2/10_Pokulyta.pdf

17. Психология бизнеса. Теория и практика: ученик для магистров под. общ.ред. Н. Л. Ивановой, В. А. Штро, Н. В. Антоновой. М.: Издательство Юрайт, 2014. 509 с. Серія: Магистр. URL: https://stud.com.ua /52835/psihologiya/ metafora kulturi.

18. Ричардс А. Философия риторики. Теория метафорь [общ. ред. Н. Д. Арутюновой и М. А. Журинской]. М.: Прогресс, 1990. С. 44-67.

19. Романюха М. В. Основні функції метафори в економічному медіа дискурсі. Мова $і$ засоби масової комунікації. 2013. URL: http://ir.kneu.edu.ua/handle/2010/2566.

\section{REFERENCES}

1. Arystotel (1967). Poetyka [Poetyka]. Kyiv: Mystetstvo, 134 [in Ukrainian].

2. Arutyunova N. D., Zhurinskaya M. A. (1990). Teoriya metafory [Metaphor theory]. Moskva: Progress, 385-386 [in RF].

3. Balashova L. V. (2014). Russkaya metaforichiskaya sistema v razvitii: $X I-X X I$ vv. [Russian metaphorical system in the development: XI-XXI c.] Znak, 632 [in RF].

4. Baranov A. N. (2004). Politicheskiy diskurs : metody analiza tematicheskoy struktury i metaforiki [Political Discourse: Methods for Analyzing Thematic Structure and Metaphorics]. M., 84 [in RF].

5. Blek M. (1990). Metafora [Metaphor]. M.: Progress, 153172 [in RF].

6. Haponova L. Ye. (2013). Rol metafory u formuvanni ukrainskoi kryminalistychnoi terminolohii. Struktura i semantyka movnykh odynyts [The role of metaphors in the formation of Ukrainian criminalistic terminology]. Retrieved from https://journal.kdpu.edu.ua/filstd/article/download/ 515/512/. 
7. D'yachenko A. P. (2003) Metafory i terminologicheski ustoychivye vyrazheniya $v$ meditsine [Metaphors and terminologically set expressions in medicine]. Minsk : Novoe znanie, 426 [in RB].

8. Kelichava Ya. B. (2016). Funktsionuvannia metafory $u$ tekstakh hazety «Den»: poshuk produktyvnykh kontseptiv [The function of metaphors in newspaper texts «Day»: a search for productive concepts]. Retrieved from http://er.nau.edu.ua/ bitstream/NAU/24843/1/ stattya_Kelichava. docx.

9. Kosmeda T. A (2015). Metafora suchasnoi publitsystyky: aktualizatsiia antroponimiv (na materiali ukrainskoi ta rosiiskoi mov). [Metaphor of contemporary publicist discourse: actualization of anthroponyms] Naukovyi visnyk DDPU imeni I. Franka. Seriia «Filolohichni nauky». Movoznavstvo, 3. Retrieved from http://www.irbis-nbuv.gov.ua/cgi-bin/irbis_nbuv/cgiirbis.

10. Kryminalistyka (1998). [Criminalistics]: [pidruchnyk]. P. D. Bilenchuk, O. P. Dubovyi, M. V. Saltevskyi, P. Yu. Tymoshenko; za red. akad. P. D. Bilenchuka. K.: Atika, 416 [in Ukrainian].

11. Lakoff Dzh., Dzhonson M. (1990). Metafory, kotorymi my zhivèm [Metaphors We Live By]. Teoriya metafory: Sb. nauch. rabot. M.: Progress, 387-416 [in RF].

12. Lut K. A.(2011). Interaktsiia vizualnykh ta verbalnykh metafor u populiarnomu ekonomichnomu dyskursi [The Interaction of Visual and Verbal Metaphors in Popular Economic Discourse]. Nova filolohiia, 44. Retrieved from http://www.irbisnbuv.gov.ua/cgi-bin/irbis_nbuv/cgiirbis_[in Ukrainian].

13. Melnyk P. P. (2014). Nove metaforychne myslennia v hazetnii sportyvnii zhurnalistytsi [New metaphorical thinking in newspaper sport journalistic.].Retrieved from http://journlib.univ.kiev.ua/ index.php [in Ukrainian].

14. Odynetska L. V. (2017). Rol metafory v zasobakh masovoi informatsii [The role of the metaphor in mass media]. Retrieved from http://enpuir.npu.edu.ua/handle/123456789/13506 [in Ukrainian].

15. Panko T. I. (1994). Ukrainske terminoznavstvo [Ukrainian terminology]: [pidruchnyk]. Lviv: Svit, 216. Retrieved from http://g.lekciya.com.ua/doc/2312/index.html [in Ukrainian]. 
16. Pokulyta I. K. (2015). Zorovi metafory kultury u vizualnosmyslovomu sehmenti media komunikatsii [Visual metaphors of culture in visual-semantic segment of media communication]. Retrieved from http://novyn.kpi.ua/2015-2/10_Pokulyta.pdf [in Ukrainian].

17. Psikhologiya biznesa. Teoriya i praktika : uchenik dlya magistrov (2014). [Psychology of business. The theory and practice: manual for masters.] pod. obshch.red. N. L. Ivanovoy, V. A. Shtro, N. V. Antonovoy. M.: Izdatel'stvo Yurayt, 509. Retrieved from https://stud.com.ua/52835/psihologiya/metafora [in Ukrainian].

18. Richards A. (1990). Filosofiya ritoriki Teoriya metafory [The philosophy of oratory. The theory of metaphor]. [obshch. red. N. D. Arutyunovoy i M. A. Zhurinskoy]. M.: Progress, 44-67 [in RF].

19. Romaniukha M. V. (2013) / Osnovni funktsii metafory $v$ ekonomichnomu media dyskursi [Main functions of metaphor in economic media discourse]. Mova i zasoby masovoi komunikatsii. Retrieved from http://ir.kneu.edu.ua/ handle/ 2010/2566 [in Ukrainian].

\section{АНОТАЦІЯ}

У статті розглянуто метафору, яка виступає одним із найважливіших компонентів друкованих та електронних комунікацій.

У дослідженні констатовано, щзо в інформаційному просторі велику роль відіграють засоби масової інформачії, які історично впливають на формування світогляду сучасної людини. Мова засобів масової інформаціі як різновид національної мови еволючіонуе одночасно $з$ етнічною свідомістю та перебуває під впливом суспільних процесів. Вона відображає не лише суспільне життя, а обличчя краӥни в цілому. Тому мова сучасних засобів масової інформації багата на метафори, які сформовані на архетипах та мають різноманітне стилістичне значення.

Зосереджено увагу в мові засобів масової інформащиї на кониептуальній метафорі, яку використовують для досягнення різних ефектів. Її вживання може бути зумовлене бажанням зробити друковане слово емочүійнішим, впливовішим. 
Зроблено висновки, щзо метафора як прояв креативності мислення присутня практично в усіх типах дискурсів незалежно від їхньої типологізачії (політичному, медичному, інституційному, педагогічному, постмодерністському, феміністському та ін.). Однак в кожному з дискурсів сукупність функиій метафори є особливою в залежності від різноманітних ознак актуального дискурсу.

У процесі комунікації, зокрема в газетнопублічистичному стилі, метафора допомагає окреслити основні ідеї комунікативного повідомлення, розставити аксіологічні акценти, також апелюе до фонових знань рециипієнта й активізує до асоиіаціï.

Для дослідження метафори в публіцистиці використано як основні метод спостереження та описовий метод. На різних етапах дослідження послуговувалися методом функиіонального аналізу для визначення стилістичного навантаження метафори в публіичстиці.

Ключові слова: метафора, концептуальна метафора, засоби масової комунікації, публіцистика, суспільство.

\section{АННОТАЦИЯ}

В статье рассмотрена метафора, которая выступает одним из важнейших компонентов печатных и электронных коммуникаций.

В исследовании констатировано, что в информациионном пространстве большую роль играют средства массовой информации, которые исторически влияют на формирование мировоззрения современного человека. Язык средств массовой информации как разновидность национального языка эволючионирует одновременно с этническим сознанием и находится под влиянием общественных процессов. Она отражает не только общественную жизнь, а лицо страны в целом. Поэтому речь современных средств массовой информации богата метафорами, которые сформированы на архетипах и имеют разнообразное стилистическое значение.

Сосредоточено внимание в языке средств массовой информации на кониептуальной метафоре, которую используют для достижения различных эффектов. Eе 
употребление может быть обусловлено желанием сделать печатное слово более эмочииональным, влиятельным.

Сделаны выводы, что метафора как проявление креативности мылиления присутствует практически во всех типах дискурса независимо от их типологизации (политическом, медицинском, институцчиональном, педагогическом, постмодернистском, феминистском и др.). Однако в каждом из дискурсов совокупность функичй метафоры является особенной в зависимости от различных признаков актуального дискурса.

В процессе коммуникации, в частности в газетнопублицистическом стиле, метафора помогает очертить основные идеи коммуникативного сообщения, расставить аксиологические акценты, также апеллирует к фоновым знаниям рец̧ипиента и активизирует ассоцииацию.

Для исследования метафоры в публицистике использовано как основные метод наблюдения и описательный метод. На разных этапах исследования пользовались методом функиионального анализа для определения стилистической нагрузки метафоры в публицистике.

Ключевые слова: метафора, концептуальная метафора, средства массовой коммуникации, публицичстика, общуество. 